\title{
Comparative Study: The Role of Stem Cell In Damaged Cell
}

\author{
$\underline{\text { Fedik Abdul Rantam }}^{1,2 *}{ }_{-}$Ferdiansyah $^{2,3}$, Purwati $^{2,4}$, Dwikora Novembri Utomo ${ }^{2,3}$, Heri \\ Suroto $^{5}$ \\ ${ }^{1}$ Lab of Virology and Immunology, Dep of Microbiology, Faculty of Veterinary Medicine. \\ ${ }^{2}$ Stem Cell Research and Development Center, University of Airlangga. ${ }^{3}$ Department of \\ Orthopedic and Traumatology, RSUD. Dr. Soetomo/Faculty of Medicine University of \\ Airlangga, ${ }^{4}$ Department of Internal Medicine, RSUD Dr. Soetomo/Faculty of Medicine \\ University of Airlangga, ${ }^{5}$ Tissue Bank RSUD Dr. Soetomo/ Faculty of Medicine Airlangga \\ University, Surabaya, Indonesia
}

\begin{abstract}
Stem cell is undifferentiated cell that have some properties like self renewal and plasticity. The other properties are can differentiate into some the specific cell. Stem cell is divided into two kinds of cell base on the resource of stem cell are embryonic stem cell and adult stem cell. Base on the plasticity of stem cell can be divided into some types of cell as well as Totipotent, pluripotent, multipotent, oligopotent and unipotent. Cell type is product from the process of proliferation and differentiation from stem cell. This way the stem cell can be used to develop as comparative medicine base on the properties and function stem cell, and for therapy to repair of cell defect, tissue and organs defect, that finally can inhibit leading to the degenerative disease. Degenerative disease is tissue or organ function lost due to injury, disease, age or congenital defects without infectious disease. To make regeneration and function of cells, tissue, and organs have needed new cells from endogenous or exogenous stem cell, that can self renewal, proliferation, and differentiation, that call stem cell. Stem cells can be isolated from bone marrow, but at the last decade that stem cells can be explored from different resources like umbilical cord blood (UCB), placenta, hair follicle, adipose tissue, and dental pulp as resource stem cell for therapy. Finally, the stem cell have important role in degenerative medicine disease and also including damaged cell.
\end{abstract}

Key words: comparative, degeneration, stem cell, damaged cell, therapy

Contact person fedik.ar@gmail.com or fedik-a-r@ fkh.unair.ac.id

\section{Introduction}

The comparative medicine is a distinct discipline of experimental medicine that uses animal models of human and animal disease in translational and biomedical research. In these area can be use to study in a translational research using animal as model to manage disease like cancer, internal medicine, and orthopedic or surgery. Combining of the both subject on above that regenerative medicine is a promise of regenerating damaged cells, tissues and organs in the body under previously irreparable tissue to heal them selves, then finally can improve the quality life. 
Stem cell have multiplayer effect to generate, replace, and repair in the degenerative disease, and also can produce some molecules that can be divided into small and large molecules. These molecules have some different function as well as paracrine effect, autocrine effect to lead the micro environment became normal again, and also stimulate cell became active and leading to the proliferation, differentiation, and finally to be maturation cell.

Animal stem cell or human stem cell can be developed into many kinds of model disease as well as defect cell, tissue defect to find the new strategy to explore of the new drug discovery through molecule identification and characterization that expression on the superficial membrane cell and secretion into the extra cellular. Animal defect cell can explore and used to study of the mechanism of molecule function base on genotype and phenotype. This strategy can be developed as model to design of new drug in degenerative disease or in generally disease.

The application of animal stem cell in the experimental have been used to repair in the some cases as well as for repair tendon defect, musculoskeletal defect, spine injury, bone fracture, diabetes mellitus, and to make cloning gen, and the results can be used as model as well as comparative study. In the basic research area of stem cell were developed into like induced pluripotent stem cell (IPS), transfer nuclear. In the many kinds of event researchers or scientist have found new drugs discovery that have been done base on the cell model as paradigm of molecular biology activity.

Under apoptotic conditions in cell culture secreted enzyme, but through leukocyte elastase, protease, cytokine activities can be generated. Secretion of this tRNA synthetase may contribute to apoptosis both by arresting translation and producing needed cytokines.

\section{Material and Methods}

To characterize of mesenchymal stem cell expressed small and large molecules can use immunocytochemistry, immunofluorescence, and also by using flowcytometri, but to analyze of secreted product or solubelize molecules of mesenchymal stem cell have been used indirect ELISA. Other methods to analyze of the ability of stem cell were used proliferation assay, differentiation assay, MTT, DAPI and also degenerated assay using $\beta$-galactosidase to determine of senescence cell. By Polymerase chain reaction (PCR) approach to make sure that stem cell is not infected cell by virus. To detect of stem cell quality base on mitochondria activity, and microRNA specific cancer cells were used real time-PCR, but to analyze of migration, attachment, integration of stem cell were used labeled mesenchymal stem cells (MSCs) by PKH26.

\section{Result and Discussion}

To understand of the paradigm of stem cell as comparative can be understood through a multi-step pathway allows some of regulatory elements to be used to safeguard the final outcome. It is important to understand that all adult stem cell systems exist to insure that when cells within tissues expire naturally, these cells can be expeditiously replaced to provide physiological balance in the organism. Every cell in the body has a lifespan ranging from 20 
minutes to many years depending on the cell. Some circulating blood cells expire in 20 minutes after forming, while neurons exist for many years. The expiration allows the tissue to rejuvenate itself and provides the tissue with a mechanism to slowly change its properties as a function of age.

The tropism environment of stem cell is important role, and also MSCs play a central role in aspects of tissue regeneration and repair, maintenance and turnover and the control of hematopoiesis. The equal importance is the secretion of bioactive factors by MSCs that influence regeneration, turnover, and hematopoiesis. This influence is referred to as TROPHIC because the MSCs do not themselves differentiate but rather their bioactive factor secretion mediates the functional tissue outcome.

Mesenchymal stem cells (MSCs) are now known for their ability to differentiate into a number of different phenotypes or to express markers for a range of different cell phenotypes. Prior to the more recent discoveries of the multiple potential of MSCs. The effects of MSCsecreted bioactive molecules can be either direct or indirect or even both: direct by causing intracellular signaling or indirect by causing another cell in the vicinity to secrete the functionally active agent. We refer to this indirect activity as TROPHIC, consistent with the original use of this word by neurobiologists to indicate the bioactive molecules released from nerve terminals that are not neurotransmitters.

Therapy model of degenerative disease are using approach single cells through transplantation, it is suitable for the regenerative of tissue to make heal selves like repair pancreas for diabetic mellitus, heart infarction, neuron degenerative, muscle skeletal disease, glaucoma, immunodeficiency's, allergies. The mechanism of stem cell regenerated of damage cell have to through migration, attachment, homing and replacement in the damage cell. Finally endogenous or exogenous stem cell can lead to the maturation cell and integration with the neighbors of tissue. Others application of stem cell can be used therapy for other disease like arthritis, Parkinson's, Alzheimer's, cancers, stroke, dysfunction erection, alopecia, but there are some kinds too of degenerative disease can't be used using single cell but needed matrix or scaffold. This approach can be designed using tissue engineering approach especially to regenerate like degeneration of renal disease, urethra, cartilage, bone fracture, jaw defect. From the management therapy by animal have possibility benefit for human on different cases without lost human being and animal welfare.

\section{Acknowledgement}

We thank to our team at Stem Cell Research and Development Center, University of Airlangga. The Part of this research were supported by Incentive Research Grant, Ministry of Research, Technology and High Education, Indonesia Republic, 2015.

\section{References}

Caplan A.I. and James E. Dennis, 2006. Mesenchymal Stem Cells as Trophic Mediators. Journal of Cellular Biochemistry 98:1076-1084

Hendi Hendarto, Mohammad Ferry Komarhadi, Erva Darmawanti, Widjiati, Suhatno and Fedik Abdul Rantam, 2013. The Effect of Bone Marrow Transplantation on Oocyte- 
Granulosa Cell Interaction and Follicular Development of Cisplatin-Induced Ovarian Failure in Rat. J Stem Cell Res Ther 2013,

David B. Kamadjaja, Purwati, Fedik A. Rantam, Ferdiansyah, Coen Pramono, 2013. The Osteogenic Capacity of Human Amniotic Membrane Mesenchymal Stem Cell (hAMSC) and Potential for Application in Maxillofacial Bone Reconstruction in Vitro Study. J. Biomedical Science and Engineering, 2014, 7, 497-503

Rantam, FA, Purwati, Boedi Setiawan, Sony Wibisono, Ferdiansyah, Joni Wahyuhadi, Edward Mouli, Dwikora N. Utomo, Heri Suroto, Candra Bumi, 2015. Induced Monocytes-Derived HSCs (CD34+) with LPS Accelerated Homing Rat Bone Marrow-Mesenchymal Stem Cell (BM-MSCs, CD105) in Injured Pancreas. J. Biomedical Science and Engineering, 2015, 8, 333-344.

Oeke Yunita Mochammad Yuwono \& Fedik Abdul Rantam, 2014. In vitro cytotoxicity assay of Sauropus androgynus on human mesenchymal stem cells. Toxicological \& Environmental Chemistry

Andrea Augello, Roberta Tasso, Simone Maria Negrini, Ranieri Cancedda, and Giuseppina Pennesi, 2007. Cell Therapy Using Allogeneic Bone Marrow Mesenchymal Stem Cells Prevents Tissue Damage in Collagen-Induced Arthritis. Arthritis \& Rheumatism, Vol. 56, No. 4, pp 1175-1186

Keisuke Wakasugi and Paul Schimmel 1999. Two Distinct Cytokines Released from a Human Aminoacyl-tRNA Synthetase. Science Vol. 284 